\title{
The Relation of Togok Flexibility and Limb Muscle Power to Perform Power Jump Heading on Football Extracurricular of Smk Negeri 2 Muara Enim Students
}

\author{
A Prabowo ${ }^{1 *}$, Waluyo ${ }^{1}$, Marsiyem $^{1}, \mathrm{~N}$ Ihsan $^{1}$ \\ ${ }^{1}$ Faculty of Sport Science, Universitas Negeri Padang, Prof. Dr. Hamka, Padang, Indonesia \\ "Corresponding author. Email: andikapunp@gmail.com
}

\begin{abstract}
This research was conducted over three days using a test instrument to determine whether there is a relationship and effective contribution of togok flexibility and the ability of leg muscle towards Power Jump headings. This study used correlation method.The results shows that flexibility of togok $(\mathrm{Km}=0.02), \operatorname{limb}$ muscle power $(\mathrm{Km}=0.09)$, Jump heading ability $(\mathrm{Km}=0.12)$. Besides, Fcounted $=-0.89 \leq \mathrm{F}$ table $=3.56$. The correlation between X1-Y: $0.90=90 \%, \mathrm{X} 2-\mathrm{Y}: 0.98=98 \%$, and the contribution result was $=86 \%(\alpha=0.05)$. Thus, the Ha is accepted. In other words, there is significant relationship between togok flexibility and limb muscle power with the ability to jump of male student who took football extracurricular at SMK 2 Muara Enim.
\end{abstract}

Keywords: Togok flexibility, limb muscle power, jump heading, football extracurricular

\section{INTRODUCTION}

Football is one of the most famous sports in the world. It is a game played by 11 people which requires good basic techniques as the basis for playing. One technique in football that is often overlooked and considered easy is to do headings. Heading the ball must apply the right technique and movement because wrong movement lead to the difficulty to control the ball. Moreover, to head the ball while doing jumping requires the explosive power of leg muscles. It is due the strength of the abdominal muscles is coordinated with the formation of togokas preparation. Football also prioritizes many components of training and also requires a player to master the training components and physical components of flexibility since this physical component is the basic component that a player must have.

Heading a ball is the art of directing a ball using the head to push or hit the ball to a target according to Tri Septa (2009). To find out the flexibility of body trunk, it can be done with several tests; namely "sit and reach" and bridge-up. A football player is also required to have good leg muscle power because the core of football game is in the ability of the limb muscles as stated by Sukirno (2011).

Leg muscle power is a contraction of a group of limb muscles to produce motion with maximum speed and maximum strength. The muscles that perform the movement of leg muscle power start from a group of hip muscles, a group of thigh muscles, and lower leg muscle groups as the main movers in the limbs.
According to Iyakrus (2012), muscle power is a combination of strength and speed, namely the ability to exert force in a short time, to provide the best momentum for the body or object to bring it to the desired distance. Looking at the School football team that the researchers studied, this team is one of the great teams in Muara Enim Regency at the level of equivalent high school students in 2009 until 2011 the team won the high school education league in MuaraEnim Regency, even representing Muara Enim in the Student League at the provincial level of South Sumatra but was defeated by schools from other stronger districts. The observation result showed that only few member of the team used the jump heading technique as a final touch as well as higher-ranking defenders but defenders were less productive in carrying out attacks. Besides, the ball was uncontrolled because the ability to do the jump heading technique is not good. Jump heading technique in football is a technique of heading the ball using a head with a jumping position that aims to drive the ball to the opponents' goalpost. This technique is done by a player by jumping with both feet and heading the ball in the air with a backward swing and then he swings forwardly to direct the ball as desired. Nevertheless, not all players can do this technique properly and correctly.

The purpose of this study is to find out whether there is a relationship between the shape of the stick and the ability of jump heading, to find out whether there is a relationship between leg muscle power and the ability of jump heading. Besides, the researchers want to know whether there is a relationship between 
the shape of the stick and leg muscle power with the ability to jump the ball in improving the training techniques and programs for jump headings. Then, this research hypothesis is:

1. There is a relationship between the formation of strikes and leg muscle explosive power toward the ability of Jump heading balls of male students in football extracurricular SMK N 2 MuaraEnim.

2. There is no relationship between the formation of strikes and leg muscle explosive power toward the ability of Jump heading balls of male students in football extracurricular SMK N 2 MuaraEnim.

\section{Research Methodology}

The method used correlational research. Correlational research is research that looks at the relationship between variables (Kountur, 2009). The stages done were: 1) variable $\mathrm{X} 1$ is associated with variable $\mathrm{Y} .2$ ) variable $\mathrm{X} 2$ is associated with variable $\mathrm{Y}$. 3 ) variable $X 1$ with $X 2$ are associated with variable $Y$.

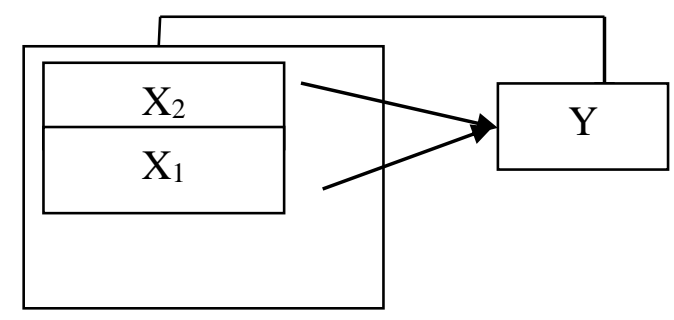

Figure 1. Correlational design.

The population in this research was 31 male students who took football extracurricular at SMKN 2 Muara Enim. The sample used was total sampling. The instrument used are Direct measurement of tooth shape Objective to measure back muscle flexibility to the back (hyper extension) (Ismaryati: 2011) and direct measurement of leg muscle power (Vertical Jump) (ismaryati: 2011). The results are described in the following table:

Table 1. Measurement Score.

\begin{tabular}{|l|l|l|}
\hline No. & Score Category & Score Range $(\mathbf{c m})$ \\
\hline 1. & Excellent & $>70$ \\
\hline 2. & Very Good & $62-69$ \\
\hline 3. & Good & $53-61$ \\
\hline 4. & Fair & $46-52$ \\
\hline 5. & Poor & $38-45$ \\
\hline
\end{tabular}

To test whether the data is normally distributed, then the curve slope test is used with the platform coefficient formula, The linearity test is intended to test whether the data obtained is linear or not. If the data is linear, then it can be continued with regression techniques.

The relations of $(\mathrm{X} 1, \mathrm{Y})$ and $(\mathrm{X} 2, \mathrm{Y})$ are using simple linear relationships or correlations, which can be analyzed using a simple correlation coefficient (Product Moment).

\section{RESULTS AND DISCUSSION}

The results of the study indicate that jointly between the size of the pitch and leg muscle power are related but not significant with the proven jump heading ability from the analysis results which obtain F count $185.42 \geq$ $\mathrm{F}$ table 3.55. Double correlation $(\mathrm{R})$ between variables free with the dependent variable has a correlation of 0.86 , and the determinant correlation of $86 \%$ or $13.2 \%$ of things proves that the jump heading ability is supported by the shape of the limb and Power of the leg muscles so that the results are as expected. After taking data from each variable, then testing the data with normality and linearity test as a condition of data analysis after being tested it turns out that the data is normal and linear, then the correlation is searched by comparing $\mathrm{F}$ count with 185.42 with $\mathrm{F}$ table with numerator 2 denominator 31 obtained 3.55 results (obtained in the distribution table F), seen from the data it shows $\mathrm{F}$ count is smaller than $\mathrm{F}$ table, all independent variables that is, the size of tokens contributes high with a coefficient of 0.90 as well as Power of leg muscles contributing to a high correlation with a coefficient of 0.98 which means that each contributes $90 \%$ and $98 \%$ to the variable Y. This is said to be a high mix of the correlation interval table quoted in Sugijono's book (2012: 18).

\section{CONCLUSION}

The results of the analysis and statistics with normality test, linearity test, multiculinierity test and multiple correlation test, obtained the results of normality test in the form of tokens. $0.019 \mathrm{Km}$, limb muscle power $\mathrm{Km0,009}$ and Jump heading ability, $\mathrm{Km}$ $-0,006$. Linearity test of $\mathrm{Y}-\mathrm{X} 1$ variable shows that Fcount $-0.5 \leq \mathrm{F}$ table 3.45 , Y-X2 variable shows that $\mathrm{F}$ count $2.54 \leq \mathrm{F}$ table 3.56. Multiculinierity test at the level of $5 \%$. The test of F-count multiple correlation $51.78 \leq \mathrm{F}$ table 3.55 means that the shape of togok and leg muscle power has a relationship but does not provide significant contribution to the jump heading ability because to jump ball headings in football is not only needed good shape of leggings and leg muscle power but also must have good technique and selection of the right timings when going to gore the ball in the air and the ability of jump heading can be done as expected 


\section{REFERENCES}

[1] Agung, Tri Septa. 2009. Kamus Pintar Sepak bola. Jakarta: Trisan Grafika

[2] Aji Sukma. 2016. Sepak bola dan strategi bertahan: Jakarta. Pandawa

[3] Aprianto. 2009. Ensiklopedia Sepak Bola: Semarang. UNES Press

[4] Arikunto, Suharsimi. 2010. Prosedur Penelitian. Yogyakarta: Rineka Cipta

[5] Bompa, T. O. 1990. Theory and Methodology of Training. Debuque: Kendal/Hunt Publishing

[6] Clive gliver. 2002 Story of football: London. United of kingdom

[7] Damayanti, Deni. 2013.Panduan Lengkap Menyusun Proposal Skripsi Tesis Disertasi untuk Semua Program Studi. Yogyakarta: Araska.

[8] Ismaryati. 2011. Tes dan Pengukuran Olahraga. Surakarta: UNS Press.

[9] Iyakrus. 2012 Sepak Takrau. Palembang : Dramata

[10] Kountur, Ronny. 2009. Metode Penelitian untuk Penyusunan Skripsi dan Tesis. Jakarta: PPM.

[11] Kurniawan Inung. 2009. Sepak Bola menyerang dan Teknik dalam Sepak bola: Semarang. UNES

[12] Margono.2010. Tes Dan Pengukuran: Bandung Sinar baru

[13] Sevila Dkk. 2006. Metodelogi penelitian: Jakarta. Akasa

[14] Sucipto Dkk. 2000. Teknik - Teknik Sepak Bola: Surabaya. Persirah cipta

[15] Sudjana, Nana dan Ibrahim. 2010. Penelitian dan Penilaian Pendidikan. Bandung: Sinar Baru Algesindo.

[16] Suharno HP. 1993. Metodologi Pelatihan. Yogyakarta: IKIP Yogyakarta.

[17] Sukirno. 2012. Ilmu Anatomi Manusia. Palembang: Dramata.

[18] Widiastuti. 2011. Kebugaran

Jasmani dan Kesehatan: Jakarta. Akasa 